
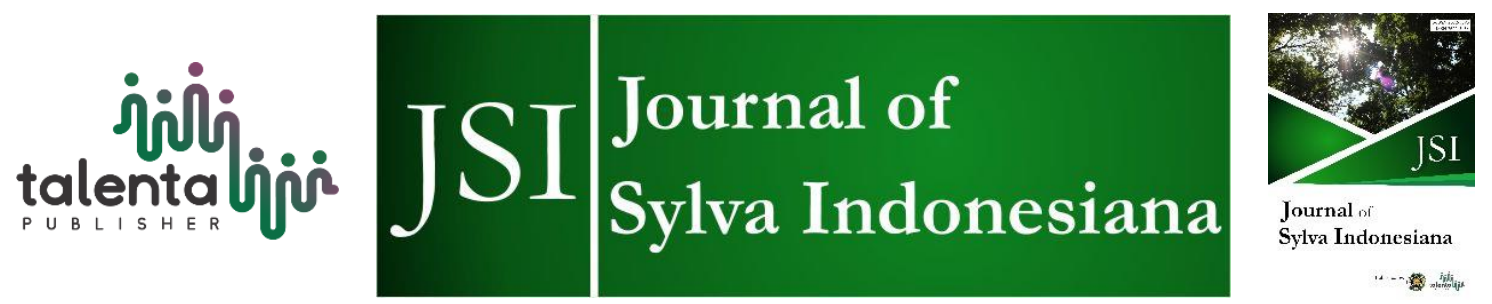

\title{
Rainfall Observation and Utilization of Rooter System Technology to Increase Water Infiltration Rate in Urban Area
}

\author{
Budi Utomo ${ }^{*}$, Juliana Rosmawati Marpaung ${ }^{1}$, Yogi Ganda Gatika \\ Togatorop $^{1}$, and Afifuddin Dalimunthe ${ }^{1}$ \\ ${ }^{I}$ Department of Silviculture, Faculty of Forestry, Universitas Sumatera Utara, Medan, Indonesia
}

\begin{abstract}
Increasing and developing infrastructure in urban areas has resulted in decreased water infiltration quality into the ground. The increasing of settlement needs and raising its price has resulted in many water catchment areas changing their function unconsciously in urban areas. This condition was ultimately triggering the loss of opportunities for rainwater to into the ground. At present, when the rainy season arrives, almost all major cities in Indonesia experience flooding. The torrential rains that lasted just 1 hour were enough to cause relatively high inundation, which varied from $30 \mathrm{~cm}$ to over $1 \mathrm{~m}$. This study aims to analyze the intensity of rainfall and its impact on the potential for flooding in urban areas and how to overcome it by utilizing rooter system technology. The results showed that the 4-way rooter system technology's influence was considerable in reducing the water level. An experimental area of $100 \mathrm{~m} 2$ treated with a rooter system of 16 pipes with a water level of $40 \mathrm{~cm}$ can infiltrate stagnant water into the soil within 120 minutes. Meanwhile, in the same area without rooter technology, it takes 400 minutes to absorb water into the soil until the stagnant water is completely gone. This proves that the rooter system technology plays a significant role in accelerating water absorption into the ground, reducing the risk of flooding.
\end{abstract}

Keyword: Intensity, Length of Rain, Puddle, Rainfall, Rooter System

Received 2 February 2021 | Revised 8 February 2021 | Accepted 24 February 2021

\section{Introduction}

The problem of flooding in urban areas today has become a difficult problem to solve. Technological developments related to infrastructure have had negative consequences on environmental aspects. Initially, most of the urban areas were green open space at the stage of urban development. However, along with the times and population growth, the need for space to accommodate the population and their activities have resulted in converting land functions from being green open space to a built-up area [1].

\footnotetext{
*Corresponding author at: Department of Silviculture, Faculty of Forestry, Universitas Sumatera Utara, Jl. Tri Dharma Ujung No. 1 Kampus USU, Medan 20155, Indonesia

E-mail address: budiutomo@usu.ac.id
} 
The development of an area or area, especially urban areas, has an impact on the environment. Inevitably, cities' rapid development without an integrated and comprehensive manner (integrated and holistic) will affect the hydrological cycle's natural processes, which will disrupt the hydrological balance. Within urban hydrology, the effects of urbanization and land-use change play an important role. The factors of urbanization aspects that affect the urban hydrological process are (1) increasing population density, and (2) increasing building density in urban areas [2].

The clearing of forest areas into settlements resulted in the loss of the forest's system. The Forest canopy has several strata to suppress the rate of rainwater dropping speed to slow down and reduce the speed of falling rainwater to the forest floor. Meanwhile, the forest floor, which has a thick layer of humus functions as a giant sponge to store and absorb large amounts of water into the soil. The conversion of forests to settlements has changed this system drastically, where the loss of trees has resulted in the loss of the system's function to inhibit the rate of falling rainwater. On the other hand, the forest floor that functions as a sponge has turned into solid soil, buildings, or other infrastructure that changes the ecological balance in the city area. Water that should have been infiltrated into every inch of land is now being channeled into ditches leading to rivers that are available in the city. These rivers were unable to receive the incoming water, resulting in overflows and inundation of floods [3].

Rainfall is strongly influenced by climatic conditions and topography of an area, so that conditions will be very different for each different region. High rainfall causes water to overflow in several rivers, causing flooding. In addition, the construction of buildings that do not comply with regulations around the watershed (DAS) is also suspected to be one of the causes of the flooding. Several other factors that influence rainfall in an area are humidity, air pressure, wind speed, and air temperature [4]. Apart from climatic factors, the soil condition in an area also dramatically affects the potential for flooding. The same type of soil with different uses will have very other effects on the potential for flooding. Forest soil and land in urban areas, although the soil type is the same, the soil density will be different so that the potential for flooding in urban areas will be greater. Based on these considerations, it is necessary to conduct research on the analysis of rainfall in the terrain area, its impact on the potential for flooding, and efforts to anticipate using rooter system technology.

\section{Materials and Methods}

This research was conducted in three areas in Medan City: Simalingkar District, Padang Bulan District, and Teladan District (Figure 1). This study used data from rainfall in three measurement locations (Simalingkar, Padang Bulan, and Teladan) for eight months, namely September 2017 to April 2018. The tools used in this study are a manual rainfall gauge, camera, stationery, and rulers. 


\subsection{Procedure}

This research was conducted in several stages, starting from secondary data collection to primary data collection. The entire procedure is carried out as follows.

\section{A. Secondary data.}

Secondary data taken is the intensity of monthly rainfall by the Oil Palm Research Center (PPKS), and this data is recorded by researchers for further tabulation as secondary data to provide information about the intensity of rainfall that occurred during eight months from September 2017 to April. 2018.

\section{B. Primary data.}

Primary data taken are: 1) The duration of rain; 2) Height of inundation; 3) The speed of water infiltration into the ground.

The rainfall length is taken every time it rains and is calculated using a stopwatch until the rain stops. Inundation height is measured every time it rains using a meter ranging from the highest inundation due to rainfall to stagnant water disappearing from the soil surface. The speed of water infiltrating the ground is taken every time it rains, which is calculated using a stopwatch until the puddle is wholly absorbed into the ground. The data obtained is then tabulated in a table to see the effect of rainfall on water infiltration duration in the city area. The research was continued with creating a rooter system to determine how the rooter system influences in helping to overcome flooding in urban areas. Making a rooter system follows the procedure for making a rooter system created by [5].

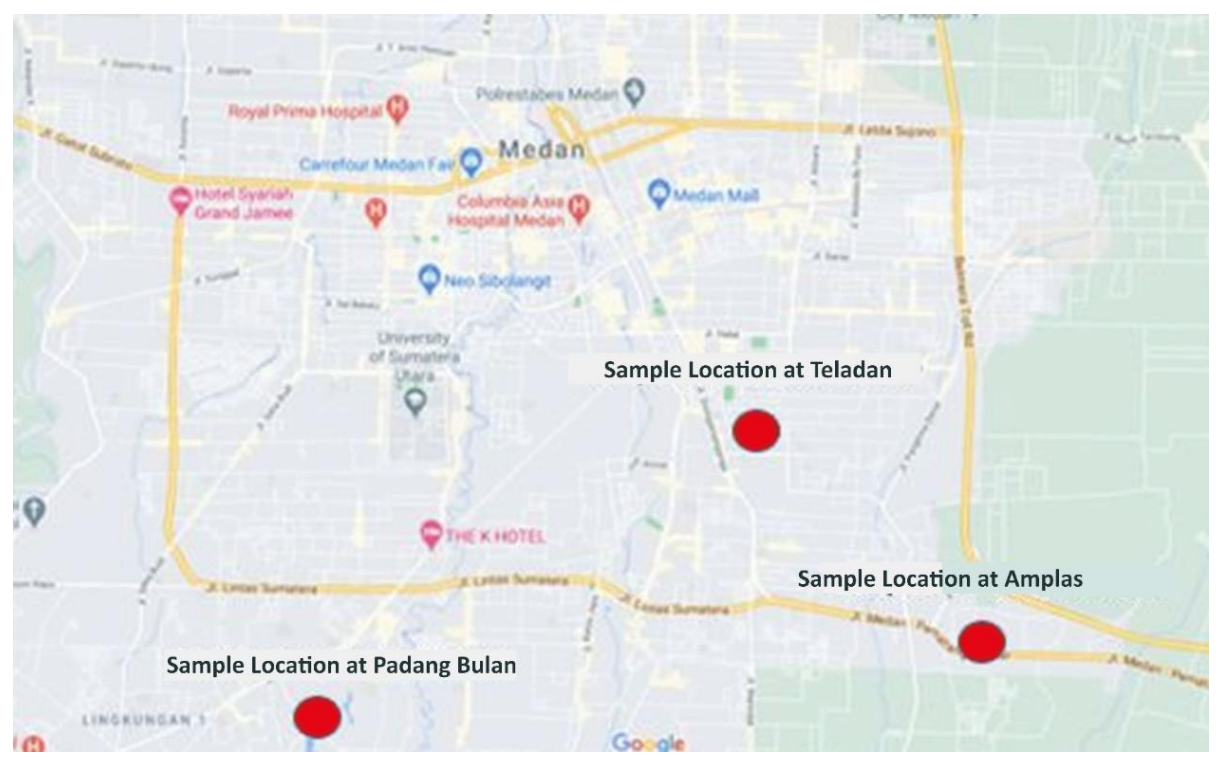

Figure 1 Samples of observations at three locations (Padang Bulan, Teladan, and Amplas) 


\subsection{Four Way Rooter System Technology Installation}

Installation of rooter system technology is carried out by drilling the ground to a depth of 2 meters with diameter hole of 5 inches. The hole making was carried out at 16 predetermined points according to the research location. Making soil holes is done at an angle of $45^{\circ}$. Then do the installation of a paralon pipe with a diameter of 4 inches with a length of 2 meters into the hole made. The pipe that is inserted into the hole is designed so that when it is in the ground, the pipe can lead to 4 points of the wind. Each pipe is spaced 5 meters from the other pipes. The placement of these observation pipes is made of an area of $100 \mathrm{~m}^{2}$ where on the edge of the observation location, plastic sacks are attached as a barrier to prevent water from escaping from the side.

An observation location of $100 \mathrm{~m}^{2}$ was made in the same area, but no drilling was carried out. Only on the other sides of the circumference are plastic sacks fitted to prevent water from leaking from the side of the observation location (Figure 2).

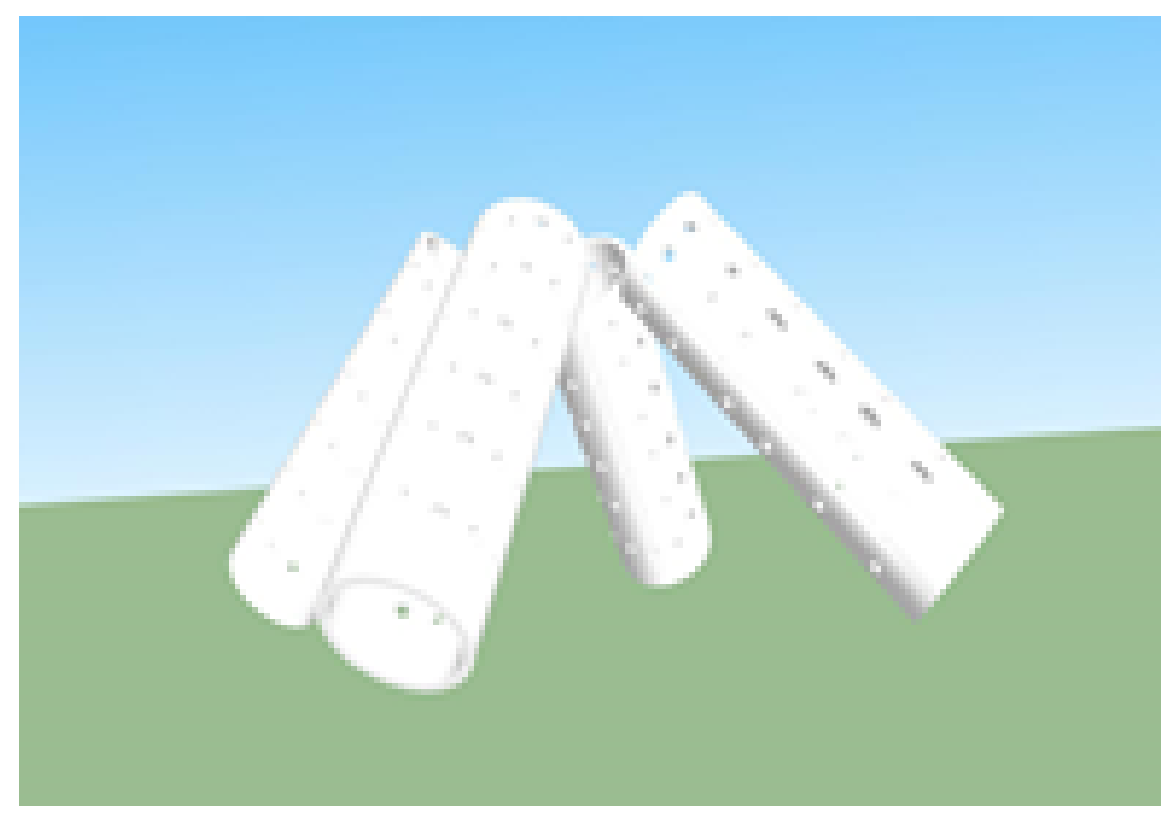

Figure 2 Installation of 4-way rooter system

\subsection{Data analysis}

Data analysis carried out in this study aims to compare the rate of infiltration rates in soil using rooter system technology with land that does not use rooter system technology. The formula used in data analysis in this study is as follows:

$$
\begin{aligned}
& \text { Volume }\left(\mathrm{cm}^{3}\right)=\text { length }(\mathrm{cm}) \times \text { width }(\mathrm{cm}) \times \text { height }(\mathrm{cm}) \\
& \text { Discharge }=\frac{\text { flow volume }}{\text { flowtme }}
\end{aligned}
$$


Flow time $=\frac{\text { flow volume }}{\text { discharge }}$

\section{Results and Discussion}

\subsection{Rainfall Intensity}

Rainfall intensity at the three measurement locations (Simalingkar, Padang Bulan, and Teladan) has different values. From the observations and measurements of rainfall intensity that have been carried out, the highest rainfall intensity occurred in Padang Bulan in October, namely $51.4 \mathrm{~mm} /$ hour. The lowest rainfall intensity occurred in Simalingkar in April, namely 4.5 $\mathrm{mm} /$ hour.

Table 1 Average rainfall intensity in three locations (Simalingkar, Padang Bulan, and Teladan) for eight months of observation

\begin{tabular}{lccc}
\hline \multirow{2}{*}{ Month } & \multicolumn{3}{c}{ Rainfall intensity (mm/hour) } \\
\cline { 2 - 4 } & Simalingkar & Padang Bulan & Teladan \\
\hline September 2017 & 36.2 & 33.2 & 18.4 \\
October 2017 & 21.2 & 51.4 & 22.8 \\
November 2017 & 26.8 & 33.9 & 23.0 \\
December 2017 & 16.4 & 38.7 & 37.8 \\
January 2018 & 30.1 & 46.5 & 33.3 \\
February 2018 & 10.5 & 14.7 & 8.1 \\
March 2018 & 5.3 & 10.1 & 6.6 \\
April 2018 & 6.3 & 11.8 & 4.5 \\
\hline
\end{tabular}

Table 2 Rain intensity in three locations in Medan City (Simalingkar, Padang Bulan and Teladan)

\begin{tabular}{|c|c|c|c|c|c|c|c|c|c|c|}
\hline \multirow{2}{*}{ No } & \multirow{2}{*}{$\begin{array}{c}\text { Rain Criteria / } \\
\text { Rainfall Intensity } \\
\text { (mm/hour) }\end{array}$} & \multirow{2}{*}{ Location } & \multicolumn{8}{|c|}{ Frequency in Months in 2017 to 2018 (times) } \\
\hline & & & Sep & Oct & Nov & Dec & Jan & Feb & Mar & Apr \\
\hline \multirow[t]{3}{*}{1} & Light rain & Simalingkar & 8 & 9 & 3 & 5 & 7 & 4 & 2 & 2 \\
\hline & $0.10-19.9$ & Padang Bulan & 7 & 5 & 3 & 3 & 8 & 5 & 2 & 2 \\
\hline & & Teladan & 5 & 8 & 7 & 1 & 7 & 3 & 1 & 1 \\
\hline \multirow[t]{3}{*}{2} & Moderate rain & Simalingkar & 4 & 4 & 11 & 2 & 4 & 2 & - & - \\
\hline & $20.0-49.9$ & Padang Bulan & 4 & 4 & 11 & 2 & 4 & 3 & 1 & \\
\hline & & Teladan & 3 & 7 & 6 & 3 & 4 & 2 & - & - \\
\hline \multirow[t]{3}{*}{3} & Heavy rain & Simalingkar & 3 & 2 & 1 & - & 2 & 1 & - & - \\
\hline & $50.0-100$ & Padang Bulan & 3 & 4 & 3 & 1 & 2 & 2 & - & - \\
\hline & & Teladan & 2 & 3 & 2 & 3 & 1 & 1 & - & - \\
\hline \multirow[t]{3}{*}{4} & Very heavy rain & Simalingkar & - & - & - & - & - & - & - & - \\
\hline & $>100$ & Padang Bulan & - & 2 & - & 1 & - & - & - & - \\
\hline & & Teladan & - & - & - & - & - & - & - & - \\
\hline
\end{tabular}

Rainfall intensity is the amount of daily rain that occurs at a time. Rainfall intensity at three measurement locations (Simalingkar, Padang Bulan, and Teladan) in the eight months of 
observation (September 2017 to April 2018) can be divided into four categories of rain criteria (light rain, moderate rain, heavy rain, and very heavy rain).

\subsection{Duration of Rainfall}

Measurement of the duration of rainfall at the three research locations resulted in different values. The highest rainfall duration is at the Teladan location throughout December 2017, which ranges from 46.47 minutes. The lowest rainfall duration was found in Padang Bulan at the same location in April 2018, namely 4.03.

Table 3 Average duration of rain at three locations (Simalingkar, Padang Bulan and Teladan)

\begin{tabular}{lccc}
\hline \multicolumn{1}{c}{ Month } & \multicolumn{3}{c}{ Duration of rain at three locations (minutes) } \\
& Simalingkar & Padang Bulan & Teladan \\
\hline September 2017 & 17.25 & 21.11 & 16.02 \\
October 2017 & 13.57 & 19.25 & 17.82 \\
November 2017 & 18.07 & 12.2 & 13.71 \\
December 2017 & 23.85 & 40.28 & 46.47 \\
January 2018 & 16.44 & 23.33 & 18.02 \\
February 2018 & 10.31 & 12.32 & 10.03 \\
March 2018 & 5.11 & 7.27 & 5.12 \\
April 2018 & 5.24 & 7.09 & 4.03 \\
\hline
\end{tabular}

Measurement of the duration of rainfall at each location produces different values. The distribution of rainfall throughout the earth's surface is closely related to air pressure. According to [6], air pressure is an element and climate control that is very important for the life of creatures on earth because of its role as a determinant in the distribution of rainfall. Changes in air pressure will cause changes in wind speed and direction, these changes will also affect changes in temperature and rainfall. Thus, the rainfall distribution throughout the earth's surface is closely related to the air and wind pressure system. The high air pressure can cause high rainfall in an area that carries a cloud accumulation to an area until cloud accumulation that can produce rain.

\subsection{Inundation Height}

The inundation height at the three research locations had different values. The highest inundation height occurred at the Padang Bulan location in December 2017. Those were $82 \mathrm{~mm}$, while the lowest was found in all observation locations from March to April 2018. February to April 2018 has entered the dry season, so that rainfall is very low. The location that has the highest puddle is in Padang Bulan. Padang Bulan area is an area that often experiences high rainfall. According to [7] that Padang Bulan is a lowland area. The factors that influence flooding in the area are rainfall, land use (types of land use in the area are settlements, rice fields, water bodies and mixed gardens). 
Table 4 Average height of inundation at three locations (Simalingkar, Padang Bulan and Teladan)

\begin{tabular}{lccc}
\hline \multirow{2}{*}{ Month } & \multicolumn{3}{c}{ Inundation height at three locations (mm) } \\
& Simalingkar & Padang Bulan & Teladan \\
\hline September & 54 & 53 & 15 \\
October & 54 & 64 & 73 \\
November & 54 & 54 & 60 \\
December & 66 & 82 & 62 \\
January & 48 & 54 & 44 \\
February & 5 & 6 & 4 \\
March & 0 & 0 & 0 \\
April & 0 & 0 & 0 \\
\hline
\end{tabular}

\subsection{Duration of Inundation to Infiltrate the Ground}

The results of measuring the duration of inundation to infiltrate the soil at each research location have different values. The duration of inundation to infiltrate the soil carried out within eight months vary depending on the intensity of rainfall in that location. The longest infiltration value was in the Padang Bulan area, which was 16 minutes, which occurred in December 2017. While the fastest infiltration value was found in all regions in March and April 2018, which was 0 minutes. This happens because these months have entered the dry season, where the rainfall is very low or nonexistent.

Table 5 Average duration of standing rainwater infiltrating the ground in three locations (Simalingkar, Padang Bulan, and Teladan)

\begin{tabular}{lccc}
\hline Month & $\begin{array}{c}\text { Duration of inundation to infiltrate the ground at three } \\
\text { locations (minutes) } \\
\text { Padang Bulan }\end{array}$ & Teladan \\
\hline September & 13 & 11 & 6 \\
October & 11 & 18 & 8 \\
November & 10 & 8 & 8 \\
December & 7 & 16 & 9 \\
January & 7 & 14 & 10 \\
February & 5 & 7 & 3 \\
March & 1 & 1 & 0 \\
April & 0 & 0 & 0 \\
\hline
\end{tabular}

The duration required for rainwater to infiltrate the soil is long enough to cause puddles for quite a long time. Inundation that occurs causes community activities to be disrupted and inundates settlements or infrastructure classified as flooding. The flood was caused by two factors, namely natural factors and anthropogenic factors. Examples of biological factors include high rainfall intensity and regional characteristics in the form of a basin area. Meanwhile, some anthropogenic factors reduce excessive infiltration areas and make high buildings that have not adjusted to the available drainage. 
In general, most of the three observation locations belong to the Ultisols sub-order [8]. Ultisol soil in the North Sumatra region consists of several sub-orders, including Typic Hapludults and Typic Paleudults. Ultisol soil is one type of soil in Indonesia that has a wide distribution. Ultisols can develop from various parent materials, which are acidic to alkaline. Ultisols are characterized by the accumulation of clay on the subsurface horizon, thereby reducing water absorption and increasing surface runoff and soil erosion because ultisol soil fertility is in the top layer's organic matter content. The type of soil in this city has the same soil type as the type of soil in natural forests in North Sumatra, namely the Ultisol soil type.

Even though they have the same soil type, the effect of rainfall in forest areas and urban areas is very different. The forest has never experienced flooding, while in urban areas, it has experienced flooding. The land in the city has changed due to population density and house buildings. As a result, water absorption has decreased. If there is rain with a high enough intensity and a long duration, the soil cannot infiltrate the water because it is saturated, causing flooding. This condition is exacerbated by the lack of public awareness of making water infiltration, covering the yard with cement to channel all rainwater to drainage [9].

\subsection{Use a router system to speed up the infiltration rate}

The results showed that a land area of $100 \mathrm{~m} 2$ that used a rooter system showed very different values from a land area of $100 \mathrm{~m} 2$ that did not use a rooter system. Significant differences in value occur because of differences in the rate of water infiltration into the soil. In the land that was engineered with rooter system treatment, the infiltration rate into the soil increased three times faster than the rate of infiltration of water into the soil without rooter system engineering (Figure 2). A 4-way rooter system built by punching a hole in the ground as deep as 2 meters at a 450 angle opposite each other is very effective at absorbing water into the ground. At the same water volume, using a rooter system only takes 120 minutes to infiltrate water, while in an untreated rooter system, it takes up to 400 minutes (Figure 3). This means that the rooter system is very effectively applied to urban lands to reduce flooding potential.

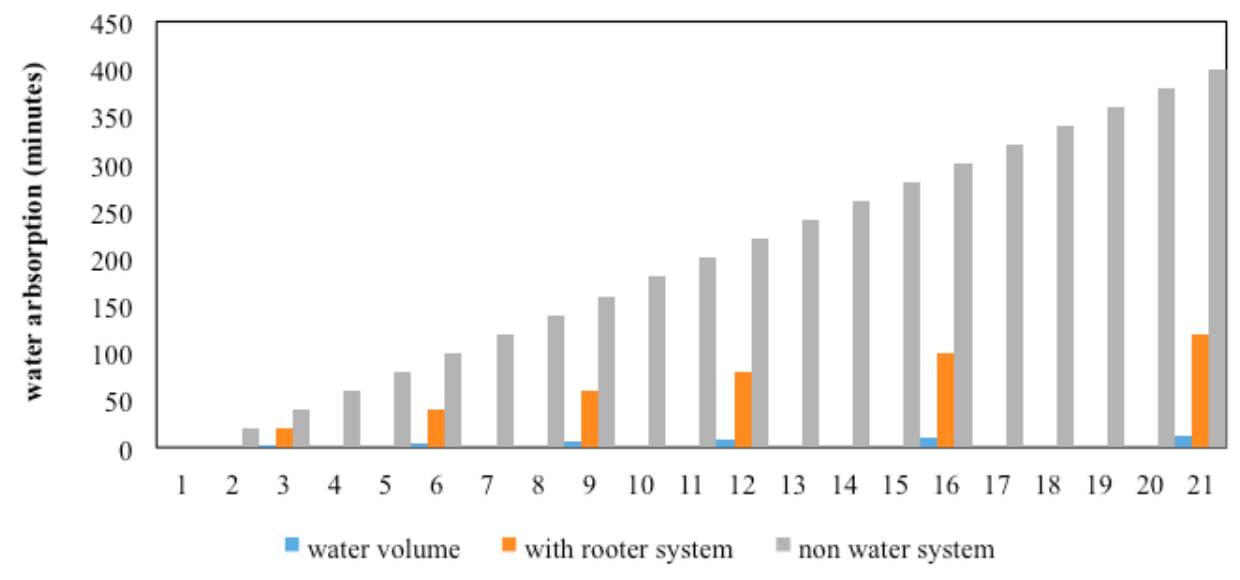

Figure 3 Comparison of the water infiltration rate into the soil at the same volume of water between areas treated with a rooter system and without a rooter system 


\section{Conclusions}

The utilization of rooter system technology on waterlogged land allows it to accelerate the absorption of water from the soil surface into the soil. Inundation that occurs can be overcome by using rooter system technology. Installation of a rooter system on sedimentary soil or sandy texture makes water absorbed faster than clay soil.

\section{Acknowledgement}

The author would like thanks to the Ministry of Research, Technology, and Higher Education for the research funding.

\section{REFERENCES}

[1] Adisasmita, and Raharjo, R. Pembangunan Kawasan Dan Tata Ruang, Graha Ilmu, Yogyakarta, 2013.

[2] Kusmadewi, and Luthfi, D. Arahan Spasial Teknologi Drainase Untuk Mereduksi Genangan Di Sub Daerah Aliran Sungai Watu Bagian Hilir, 2012.

[3] Center for Watershed Protection and US Forestry Service, 2008, "Watershed Forestry Research Guide," [Online]. Available: www.forestsforwatersheds.org/reducestormwater/. [Accessed: 20 Desember 2020).

[4] Saud, I. "Kajian Penanggulangan Banjir di Wilayah Pematusan Surabaya Barat," Jurnal Aplikasi Dosen D3 Teknik Sipil, vol. 3, no. 1, pp. 90-100. 2007.

[5] Utomo, B. "Strategi Penerapan Sumur Resapan Sebagai Teknologi Ekodraenase di Kota Medan," Report, Forestry Faculty, University Sumatera Utara, 2016.

[6] Pradipta, N. R., Paskuat, S., and Pengarapen, B. "Analisis Pengaruh Curah Hujan di Kota Medan Teknik Matematika," Teknik Matematika, vol. 1, no. 5, pp. 459-468. 2013.

[7] Rahmawaty. "Hutan Fungsi dan Peranannya Bagi Masyarakat," Report, Faculty of Agriculture. University of North Sumatra, 2004.

[8] Hardjowigeno, S., and Luthfi, R, M., Paddy Land: Characteristics, Conditions, and Problems of Paddy Land in Indonesia, Bayu Media, Malang, 2005.

[9] Tolaka, W. Wardah., and Rahmawati. Sifat Fisik Tanah pada Hutan Premier, Agroforestri dan Kabun Kakao di Subdas Saluopa, Desa Leboni, Kecamatan Pamona Puselemba, Kabupaten Poso. Warta Rimba, vol. 1, no. 1, pp. 5-25. 2013. 